\title{
ACKNOWLEDGMENTS: A BOOK IS BORN
}

\section{$T_{h}$}

his book was born out of the unrelated acts of people separated by different times and places. The first were my parents, who created laughter and unconditional love through our darkest, bitterest hours. Then came my siblings, who were there in good and in bad times. The memories they left are the foundations of this book.

Min Moeun, Peth Doeum, and Chea Sek rescued me, protected me, and helped me to escape Cambodia and thus death. This book is here because they existed and cared enough to give me a helping hand.

Out of the Thailand refugee camp to America, Cousin Ang Khen Chen and her husband Chun Chen supported me, opened their home to me, and became my foster parents. My time with them nurtured the rage and skills that created this book.

Friends touched my life in different ways. Brian T. Ellis, Bob Fonda, Phillipe Poulin, Brad and Mary Perkins, the late Dr. John Stephens and his wonderful family, the late Dr. and Mrs. Jan J. Muller, the late Mr. and Mrs. David Roach, the late David A. Linsdell, and so many others who had inspired me to finish this book were all part of the story.

I am particularly and extremely grateful to Pamela Denchfield and Jaime Cabrera, my two fabulous editors. They invested much of their time and energy to help shape and polish this book. Also, special appreciation goes to Dr. David P. Chandler, Dr. Craig Etcheson, Dr. Alex Hinton, Dr. Dan Savin, (the dearly departed) Dith Pran, Kim DePaul, Les Moscoso, Helen Maffei, Youk Chhang, Loung Ung, Reach Sambath, and countless extraordinary others who read the first drafts. Generous with time and knowledge, they helped much to ease this book's birth.

Above all, I am grateful to Thavy, my dear wife of twenty-five years, who gave me unconditional love and support, without which I would not have made it this far.

Oaur khun chran (thank you very much). 
